\title{
Calcimimetic R-568 effects on activity of R990G polymorphism of calcium-sensing receptor
}

\author{
Annalisa Terranegra $^{1 \star}$, Anita Ferraretto ${ }^{2 \star}$, Elena Dogliotti ${ }^{1}$, Milena Scarpellini ${ }^{1}$, \\ Sabrina Corbetta ${ }^{3}$, Anna Maria Barbieri ${ }^{4}$, Anna Spada ${ }^{4}$, Teresa Arcidiacono ${ }^{5}$, \\ Francesco Rainone ${ }^{5}$, Andrea Aloia ${ }^{1}$, Daniele Cusi ${ }^{1}$, Giuseppe Vezzoli ${ }^{5}$ and Laura Soldati ${ }^{1}$ \\ Departments of ${ }^{1}$ Medicine Surgery and Dentistry, ${ }^{2}$ Medical Chemistry, Biochemistry and Biotechnology, ${ }^{3}$ Medical and Surgical Sciences, IRCCS Policlinico San Donato \\ and ${ }^{4}$ Medical Sciences, IRCCS Fondazione Ospedale Maggiore Policlinico, Mangiagalli, Regina Elena, Università degli Studi di Milano, 20122 Milan, Italy \\ ${ }^{5}$ Unit of Nephrology, Dialysis and Hypertension, IRCCS San Raffaele Hospital, 20132 Milan, Italy \\ (Correspondence should be addressed to A Terranegra who is now at Dipartimento di Medicina Chirurgia e Odontoiatria, Università degli Studi di Milano, \\ Via Fratelli Cervi 93, 20090 Segrate, Milan, Italy; Email: annalisa.terranegra@unimi.it) \\ *(A Terranegra and A Ferraretto contributed equally to this work)
}

\begin{abstract}
Previous studies have demonstrated a gain-of-function of the calcium-sensing receptor (CASR) gene R990G polymorphism. In this study, activation of the R990G CASR stably transfected in HEK-293 (HEK-990G) cells compared with that of the common variant (HEK-wild-type (WT)) by increasing concentrations of $\mathrm{CaCl}_{2}$ or calcimimetic R-568 caused significantly higher intracellular free calcium concentration $\left(\left[\mathrm{Ca}^{2+}\right]_{\mathrm{i}}\right)$ and lower $\mathrm{Ca}-\mathrm{EC}_{50}$. Moreover, the $\left[\mathrm{Ca}^{2+}\right]_{\mathrm{i}}$ oscillation percentage was higher with a larger sinusoidal pattern in HEK-990G. R-568 induced a shift of the oscillatory events from 4 to $2 \mathrm{mmol} / \mathrm{l}$ extracellular calcium concentration in HEK-990G cells and increased the sinusoidal oscillation percentage in comparison with HEK-WT. Preincubation with thapsigargin or phospholipase C inhibitors completely prevented oscillations in both cell lines, consistent with the involvement of the inositol trisphosphate pathway, while protein kinase $\mathrm{C}$ inhibitor prevented oscillations in HEK-WT cells only. Finally, $\mathrm{CaCl}_{2}$ and $\mathrm{R}-568$ caused a significant increase in p44/42 extracellular signaling-regulated kinase phosphorylation, with the mean Ca-EC $\mathrm{C}_{50}$ values being significantly lower in HEK-990G. Our findings demonstrated that the $990 \mathrm{G}$ allele is associated with high sensitivity to $\mathrm{R}-568$, which provided new evidence for differences in CASR signaling.
\end{abstract}

Journal of Molecular Endocrinology (2010) 45, 245-256

\section{Introduction}

The calcium-sensing receptor (CASR) is a G-proteincoupled membrane receptor involved in the regulation of cellular calcium metabolism. The receptor senses changes in extracellular calcium concentration $\left(\left[\mathrm{Ca}^{2+}\right]_{\mathrm{o}}\right)$ and activates different intracellular pathways (Ward 2004, Tfelt-Hansen \& Brown 2005, Huang \& Miller 2007, Lorenz et al. 2007). In particular, CASR activation triggers calcium mobilization from intracellular stores through inositol trisphosphate $\left(\mathrm{IP}_{3}\right)$ receptors and activation of the mitogen activated protein kinase (MAPK) cascade through p44/42 extracellular signaling-regulated kinase (ERK) phosphorylation. These events are facilitated by the scaffolding protein filamin A. The changes in intracellular free calcium concentration $\left(\left[\mathrm{Ca}^{2+}\right]_{\mathrm{i}}\right)$ induced by CASR activation show an oscillation pattern (Breitwieser \& Gama 2001) that has been proposed to play a key role in regulating various pathways, i.e. $\mathrm{Ca}^{2+} /$ calmodulin-dependent protein kinase II (Soderling et al. 2001), protein kinase C (PKC; Oancea \& Meyer 1998, Mogami et al. 2003,
Bartlett $e$ al. 2005), RAS, and the ERK cascade (Kupzig et al. 2005). Moreover, calcium oscillations have been postulated to dynamically increase the cross talk between multiple signaling pathways, allowing the cell to encode more information and generate complex responses.

At the systemic level, CASR mediates the $\left[\mathrm{Ca}^{2+}\right]_{0}$-induced inhibition of parathyroid hormone (PTH) secretion in the parathyroid gland and calcium reabsorption in the kidney. Many rare CASR mutations have been described in humans. Patients with loss-of-function mutations are characterized by hypocalciuria and hypercalcemia, while those with gain-of-function mutations show high urinary calcium excretion and hypocalcemia (Bai et al. 1996, Egbuna \& Brown 2008). The intracellular tail of the receptor has three nonconservative polymorphisms, i.e. A986S, R990G, and Q1011E. We previously found an association between the R990G polymorphism and primary hypercalciuria in patients with and without kidney stones (Vezzoli et al. 2002, 2007). Moreover, we demonstrated that transfection of the $990 \mathrm{G}$ variant in HEK-293 cells induced a gain-of-function of the receptor (Vezzoli et al. 2007). In agreement with the 
in vitro phenotype, patients with primary or secondary hyperparathyroidism (PHPT and SHPT) with the 990G allele were found to have lower levels of serum PTH (Yamauchi et al. 2001, Scillitani et al. 2004, Corbetta et al. 2007a, Wang et al. 2007) and ionized calcium (Yano et al. 2000). Accordingly, the 990R allele was found to be associated with higher levels of both PTH and ionized calcium in comparison with 990G carriers in healthy Chinese women (Yokoyama et al. 2002). Although most studies obtained in different populations confirmed the gain-of-function of the CASR 990G allele, a few studies failed to find this association (Harding et al. 2006, Kelly et al. 2006).

Calcimimetic drugs are allosteric modulators, which enhance CASR sensitivity to extracellular calcium (Nemeth 2004, Trivedi et al. 2008). In particular, it has been demonstrated that one of these compounds, $\mathrm{R}-568$, at nanomolar concentrations increased $\left[\mathrm{Ca}^{2+}\right]_{\mathrm{i}}$ concentrations in bovine parathyroid cells and inhibited PTH secretion, with these effects being detectable only in the presence of extracellular calcium (Nemeth et al. 1998). Based on these properties, the calcimimetic agent AMG073 (cinacalcet) has been introduced for the treatment of patients with SHPT and very recently approved for patients with PHPT (Block et al. 2004, Sajid-Crockett et al. 2008). However, the response to cinacalcet is highly variable, probably related to different nutritional or genetic background. Interestingly, a recent report by Rothe et al. (2005) showed that SHPT patients carrying the CASR $990 \mathrm{G}$ allele were more responsive to treatment with calcimimetic compounds than patients without this allele. The aim of this study was to define in detail the impact of the R990G polymorphism on the receptor activity by examining at which level of the $\mathrm{IP}_{3}$ signaling pathway the two CASR variant proteins differ as well as investigating whether the two CASR variant proteins have a different response to treatment with the calcimimetic R-568. To address these issues, we used HEK-293 cells stably transfected with 990R or 990G alleles (Vezzoli et al. 2007) and investigated the cellular functions at different levels.

\section{Materials and methods}

\section{Cell culture and transfection}

Human embryonic kidney cells HEK-293 (Cell Bank, Istituto Scientifico Tumori, Genoa, Italy), which do not express endogenous CASR, were transfected with polymorphic CASR (990G), kindly provided by Dr Jianxin Hu (NIH, Bethesda, MD, USA), or wild-type (WT) CASR (990R), obtained by site-directed mutagenesis, as we have described previously (Vezzoli et al. 2007). Briefly, HEK-293 cells stably expressing human CASR were selected by geneticin (Sigma Chemicals).
Colonies were selected after 1-2 weeks, and two clones (HEK-WT cells and HEK-990G cells) were confirmed to express similar levels of the CASR protein by western blotting with monoclonal anti-CASR antibody (Affinity Bioreagents, Golden, CO, USA) as described (Vezzoli et al. 2007), whereas no expression was found in cells transfected with empty plasmid (HEK-vector cells). Cells were grown in DMEM medium (Sigma Chemicals), supplemented with $10 \% \mathrm{v} / \mathrm{v}$ fetal bovine serum, $1 \% \mathrm{v} / \mathrm{v}$ penicillin/streptomycin, and $1 \mathrm{mg} / \mathrm{ml}$ geneticin (Sigma Chemicals), under standard conditions $\left(5 \% \mathrm{CO}_{2}, 37^{\circ} \mathrm{C}\right)$.

\section{Fluorescence measurements of $\left[\mathrm{Ca}^{2+}\right]_{i}$ in whole cell population}

$\left[\mathrm{Ca}^{2+}\right]_{\mathrm{i}}$ was measured in CASR-expressing cells (about $5 \times 10^{5} \mathrm{cells} / \mathrm{ml}$ for each experiment). Cells were loaded with $1 \mu \mathrm{M}$ fura-2 AM (Sigma Chemicals), at $37^{\circ} \mathrm{C}$ for $45 \mathrm{~min}$, as described previously (Soldati et al. 1999, Vezzoli et al. 2007). The transfected cells with empty vector or untransfected HEK-293 cells were tested as controls. The calcimimetic compound R-568, kindly provided by Amgen Inc. (Thousand Oaks, CA, USA), was added at the concentration range of $0-2 \mu \mathrm{mol} / \mathrm{l}$ just before the beginning of fluorescence measurements. $\left[\mathrm{Ca}^{2+}\right]_{\mathrm{o}}$ was increased stepwise by addition of $\mathrm{CaCl}_{2}$ at the following concentrations: $0 \cdot 6,0 \cdot 8,1 \cdot 2,1 \cdot 8,3 \cdot 6,4 \cdot 6$, $6 \cdot 6,8 \cdot 6,10 \cdot 6$, and $12 \cdot 6 \mathrm{mmol} / 1$ (Pearce et al. 1996). The $\left[\mathrm{Ca}^{2+}\right]_{\mathrm{i}}$ was calculated from the ratio of the fluorescence emission recorded at the two-excitation wavelengths, as described previously (Grynkiewicz et al. 1985, Soldati et al. 1999). Transient responses of $\left[\mathrm{Ca}^{2+}\right]_{\mathrm{i}}$ were normalized according to Pearce et al. (1996) and Vezzoli et al. (2007). The effective $\left[\mathrm{Ca}^{2+}\right]_{\mathrm{o}}$ giving one-half of the maximal response $\left(\mathrm{Ca}-\mathrm{EC}_{50}\right)$ was calculated for HEK-WT and HEK-990G. In other experiments, the cells maintained at the same $\left[\mathrm{Ca}^{2+}\right]_{0}$ concentration of $1 \mathrm{mmol} / \mathrm{l}$ were added stepwise with R-568 from 0.001 to $10 \mu \mathrm{mol} / \mathrm{l}$ and $\mathrm{EC}_{50}$ was calculated $\left(\mathrm{R}-568-\mathrm{EC}_{50}\right)$.

\section{Fluorescence measurements of $\left[\mathrm{Ca}^{2+}\right]_{i}$ in single cells}

Cells were seeded on glass coverslips $\left(1 \times 10^{5}\right.$, each $)$ and after 3 days were incubated at $37^{\circ} \mathrm{C}$ for $20 \mathrm{~min}$ with fura-2 AM $(1 \mu \mathrm{mol} / \mathrm{l}$; Sigma Chemicals $)$ in a KrebsRinger-HEPES solution (KRH) having a minimal salt formulation (Gama et al. 1997), The coverslip with fura2-loaded cells was mounted on a $37^{\circ} \mathrm{C}$ thermostatted (TC-202 A, Medical System Corporation, New York, NY, USA) perfusion chamber (PDMI-2, Medical System Corporation) placed on a microscope stage (TE 200, Nikon, Tokyo, Japan) equipped with a High-Speed Dynamic Video Imaging System, Quanticell 700 (Applied Imaging, Sunderland, UK). When required, 
the calcimimetic R-568 $(0 \cdot 01,0 \cdot 05$, and $0 \cdot 1 \mu \mathrm{mol} / \mathrm{l})$ was added after the fura-2 loading in the KRH, buffering the cells. Cells were stimulated with increasing $\mathrm{CaCl}_{2}$ $(0 \cdot 5,1,2$, and $4 \mathrm{mmol} / \mathrm{l})$. According to Grynkiewicz et al. (1985), background subtracted ratio images $(340 / 380 \mathrm{~nm})$ were collected at $510 \mathrm{~nm}$ fluorescence emission through a $\times 40$ oil immersion objective and were used to calculate the $\left[\mathrm{Ca}^{2+}\right]_{\mathrm{i}}$ within the cells. All the experiments used 80-100 cells/optical field. Responsive cells were identified as cells responding to any stimulation with $\left[\mathrm{Ca}^{2+}\right]_{\mathrm{i}}$ increments equal or above $20 \mathrm{nmol} / 1$ (Miedlich et al. 2002). The mean single maximum $\left[\mathrm{Ca}^{2+}\right]_{\mathrm{i}}$ rise was calculated for each single cell by difference between baseline and peak value after any stimulation and averaged for all the analyzed cells. Oscillations were identified as three successive fluctuations in the $\left[\mathrm{Ca}^{2+}\right]_{\mathrm{i}}$ after the first main cellular peak. Sinusoidal oscillations in $\left[\mathrm{Ca}^{2+}\right]_{\mathrm{i}}$ are defined as regular fluctuations observed on top of an elevated level of calcium; thus, they represent subsequent calcium increases, after the main peak response, that do not return to the baseline. Transient oscillations are defined as discrete transients of $\left[\mathrm{Ca}^{2+}\right]_{\mathrm{i}}$ due to baseline spiking behavior (Berridge \& Potter 1990). The frequency of the oscillatory phenomena was determined counting the number of oscillatory events $/ \mathrm{min}$.

\section{Inhibitors and activators of CASR signaling pathways}

The sarco/endoplasmic reticulum $\mathrm{Ca}^{2+}$-ATPase (SERCA) inhibitor thapsigargin (Sigma Chemicals), the phospholipase C (PLC) inhibitor U73122 (Sigma Chemicals), the PKC activator phorbol 12,13-dibutyrate (PDBu; Sigma Chemicals), and the PKC inhibitor Ro-318220 (Sigma Chemicals) were prepared as stock solution in dimethylsulfoxide (DMSO) and diluted at the desired concentration in the KRH, buffering the cells before starting the experiment. A preincubation was performed before $\mathrm{CaCl}_{2}$ stimulation as following: $5 \mathrm{~min}$ for $1 \mu \mathrm{mol} / 1$ thapsigargin, $10 \mathrm{~min}$ for $10 \mu \mathrm{mol} / \mathrm{l} \mathrm{U} 73122$, 5 min for PDBu at the different concentrations used $(0 \cdot 01,0 \cdot 05$, and $0 \cdot 1 \mu \mathrm{mol} / \mathrm{l})$. In the case of Ro-318220, cells were seeded on collagen-coated glass coverslips, preincubated with different Ro-318220 concentrations $(0 \cdot 625,1 \cdot 25$, and $2 \cdot 5 \mu \mathrm{mol} / \mathrm{l})$ for $60 \mathrm{~min}$ and fura-2 was added in the last $20 \mathrm{~min}$. At $2.5 \mu \mathrm{mol} / \mathrm{l}$ both types of cells showed marked signs of suffering. Therefore, this dose was eliminated by the experiments.

\section{Determination of ERK1/2 phosphorylation}

For the determination of p44/42 ERK1/2 phosphorylated proteins, monolayers of serum-starved transfected or nontransfected HEK-293 cells were incubated at $37^{\circ} \mathrm{C}$ in serum-free medium containing $0.2 \% \mathrm{w} / \mathrm{v}$ BSA with varying levels of $\mathrm{CaCl}_{2}(0 \cdot 5-15 \mathrm{mmol} / \mathrm{l})$ and of R-568 $(0 \cdot 01,0 \cdot 05$, and $0 \cdot 1 \mu \mathrm{mol} / \mathrm{l})$ as described previously (Corbetta et al. 2002). Briefly, at the end of the incubation period $(10 \mathrm{~min})$, cell lysates were obtained by using lysis buffer supplemented with $0.1 \mathrm{mmol} / \mathrm{l}$ sodium vanadate, $1 \mathrm{mmol} / 1$ phenylmethylsulphonyl fluoride, $10 \mathrm{mmol} / \mathrm{l}$ benzamidine, $2 \mu \mathrm{g} / \mathrm{ml}$ leupeptine, and complete phosphatase inhibitor cocktail (Roche Diagnostics). In all, $40 \mu \mathrm{g}$ proteins were separated by $10 \% \mathrm{w} / \mathrm{v}$ SDS-PAGE, analyzed by western blotting with an anti-phospho-p44/42 ERK polyclonal antibody (Cell Signaling Technology, Beverly, MA, USA) diluted 1:2000, and detected by a chemiluminescent method (SuperSignal West Pico Chemiluminescent Substrate, Pierce, Rockford, IL, USA). Quantitative comparisons of the ERK1/2 phosphorylation were performed using a CanonScan $4400 \mathrm{~F}$ and a TotalLab version 2.01 (Nonlinear Dynamics, Newcastleupon-Tyne, UK). Nitrocellulose membranes were then stripped off antibodies and reprobed using an antiserum to ERK1/2, which detects these proteins independently of their state of phosphorylation. The response was normalized to the maximal effect obtained by $\left[\mathrm{Ca}^{2+}\right]_{\mathrm{o}}$ and the percentage of ERK1/2 phosphorylation was subtracted from the basal level of $\mathrm{CaCl}_{2}(0.5 \mathrm{mmol} / \mathrm{l})$. The $\mathrm{Ca}-\mathrm{EC}_{50}$ was calculated as described in the previous paragraph.

\section{Data analysis}

Data are reported as means \pm s.E.M. Statistical analysis was performed by Student's $t$-test and ANOVA as appropriate, with a significance level of $P<0 \cdot 05$. For fluorescence measurements, mean values were obtained from at least five to eight independent experiments. For ERK phosphorylation determination, experiments were repeated at least thrice.

\section{Results}

\section{Effect of $\left[\mathrm{Ca}^{2+}\right]_{\circ}$ and calcimimetic R-568 on CASR function in whole cell population experiments}

HEK-293 cells stably expressing WT CASR gene (HEKWT) or the mutated one (HEK-990G) were stimulated with $\mathrm{CaCl}_{2}$ in a stepwise manner (range: $0 \cdot 6-12 \cdot 6$ $\mathrm{mmol} / \mathrm{l})$ in the absence or presence of calcimimetic R-568 at different concentrations (from 0 to $2 \cdot 0 \mu \mathrm{mol} / \mathrm{l})$ and the change of $\left[\mathrm{Ca}^{2+}\right]_{\mathrm{i}}$ was continuously monitored. Figure 1 shows the ability of R-568 $(0 \cdot 1 \mu \mathrm{mol} / \mathrm{l})$ to potentiate $\left[\mathrm{Ca}^{2+}\right]_{\mathrm{i}}$ rises elicited by $\mathrm{CaCl}_{2}$ in HEK-WT. In absence of the drug, HEK-990G cells had a lower Ca-EC $_{50}$ than HEK-WT (Table 1). When R-568 was added at low concentrations, the mutated receptor was more active than the WT 


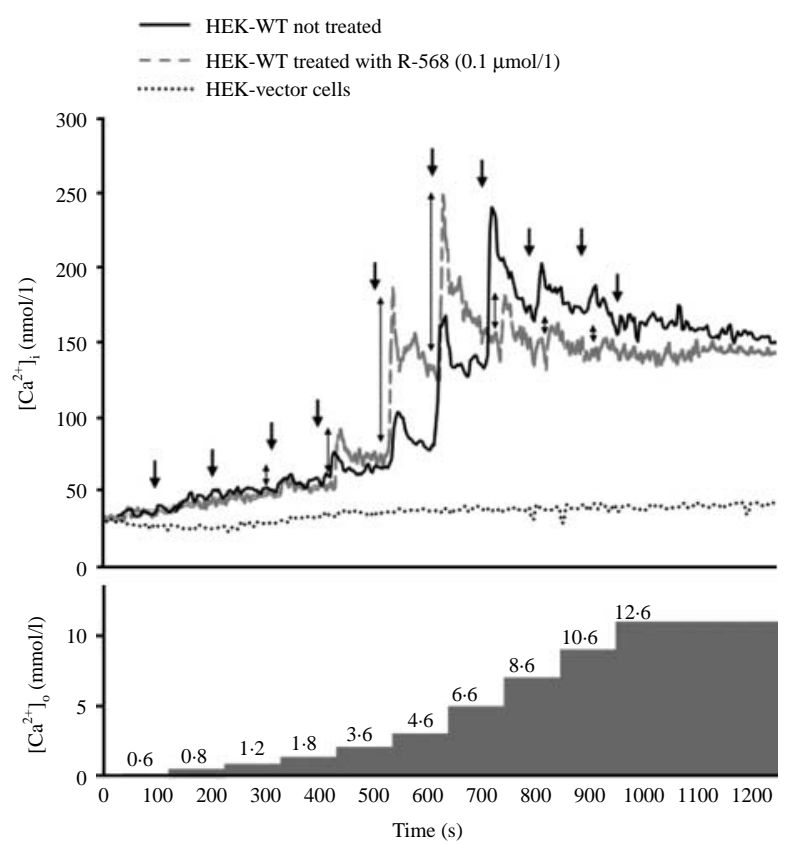

Figure 1 Stimulation with calcimimetic R-568 of HEK-293 cells stably expressing calcium-sensing receptor. The figure shows two independent experiments conducted in HEK-WT cells loaded with fura-2. The cells were stimulated by increasing $\mathrm{CaCl}_{2}$ concentrations in the presence (gray line) or absence (black line) of $\mathrm{R}-568$ calcimimetic and the $\left[\mathrm{Ca}^{2+}\right]_{\mathrm{i}}$ was recorded. HEK-293 cells transfected with empty vector (HEK-vector, dotted line) were used as negative control. At each arrow, $\mathrm{CaCl}_{2}$ was added in the medium to reach the concentration indicated in the panel below the graph. Double arrows indicate $\left[\mathrm{Ca}^{2+}\right]_{i}$ peak height in response to $\mathrm{CaCl}_{2}$ stimulation. Values shown are means \pm s.E.M. of three replicates.

receptor, as indicated by the significantly lower $\mathrm{EC}_{50}$ observed at 0.01 and $0.05 \mu \mathrm{mol} / 1$ R-568 in HEK-990G in comparison with HEK-WT (Table 1). At $0 \cdot 1 \mu \mathrm{mol} / 1$ R-568, a nonsignificant trend toward reduction was observed, while at higher concentrations $(>0.5 \mu \mathrm{mol} / \mathrm{l})$ the $\mathrm{EC}_{50}$ decreased in a relevant manner in both cell lines and the difference between the two cells disappeared. Cells transfected with empty vector or untransfected HEK-293 were tested as controls and no changes occurred in $\left[\mathrm{Ca}^{2+}\right]_{\mathrm{i}}$ (Fig. 1).

To confirm that the CASR polymorphism at codon 990 gives a different response to calcimimetic R-568, HEK-WT and HEK-990G cells were stimulated with increasing concentrations of R-568 (from 0.001 to $10 \mu \mathrm{mol} / \mathrm{l}$, Fig. 2) in presence of the same $\mathrm{CaCl}_{2}$ concentration $(1 \mathrm{mmol} / \mathrm{l})$. The R-568-EC $\mathrm{E}_{50}$ was lower in HEK-990G than in HEK-WT cells $\left(\mathrm{R}-568-\mathrm{EC}_{50}\right.$ : $0 \cdot 67 \pm 0.08 \mu \mathrm{mol} / 1 \quad(n=15) \quad$ vs $\quad 1 \cdot 41 \pm 0.09 \mu \mathrm{mol} / 1$ $(n=16)$ respectively; $P<0 \cdot 0001)$, thus indicating that the R990G polymorphism was associated with a higher sensitivity to calcimimetic R-568 than the WT receptor.

\section{Single-cell experiments: effect of $\left[\mathrm{Ca}^{2+}\right]_{0}$}

Activation of CASR followed by a single or repeated spikes of $\left[\mathrm{Ca}^{2+}\right]_{\mathrm{i}}$ (oscillations) is dependent on $\left[\mathrm{Ca}^{2+}\right]_{\mathrm{o}}$ and this phenomenon can be monitored only in single-cell experiments. HEK-WT and HEK990G cells were stimulated with stepwise increases of agents at concentrations effective in the whole cell population experiments described in the previous paragraph. In these experiments, various parameters, such as percentage of responsive cells, heights of $\left[\mathrm{Ca}^{2+}\right]_{\mathrm{i}}$ rise, oscillation type, oscillation frequency, were evaluated. As shown in Figs 3 and $4,\left[\mathrm{Ca}^{2+}\right]_{\mathrm{i}}$ rises triggered by 1 and $2 \mathrm{mmol} / \mathrm{C} \mathrm{CaCl}_{2}$ in HEK-990G cells were markedly higher than those elicited in HEKWT, while both cell lines reached the maximal $\left[\mathrm{Ca}^{2+}\right]_{\mathrm{i}}$ peak at $4 \mathrm{mmol} / 1 \mathrm{CaCl}_{2}$. Moreover, the percentage of HEK-990G cells responsive to 1 and $2 \mathrm{mmol} / 1 \mathrm{CaCl}_{2}$ was dramatically higher in comparison with the percentage of responsive HEK-WT cells (Fig. 4). At $4 \mathrm{mmol} / 1 \mathrm{CaCl}_{2}$, almost all the cells of the two cell lines responded to the agonist (Figs 3 and 4 ). After the exposure to $4 \mathrm{mmol} / \mathrm{l}$ $\mathrm{CaCl}_{2}$, both cell lines showed spontaneous oscillations. HEK-990G cells showed a higher percentage of total oscillating cells and a larger sinusoidal pattern in comparison with HEK-WT cells, while HEK-vector cells did not respond to the extracellular stimulus (Fig. 3 and Table 2). These data confirm the increased sensitivity of CASR 990G to physiological concentrations of extracellular calcium.

\section{Single-cell experiments: effect of R-568}

As for the effect of R-568 in both cell lines, we found 1) a high proportion of responsive cells, with a significantly higher increase in HEK-990G at $1 \mathrm{mmol} / \mathrm{l}$ $\mathrm{CaCl}_{2}$ at all R-568-tested concentrations, as shown in Fig. 4 ; 2) a higher mean $\left[\mathrm{Ca}^{2+}\right]_{\mathrm{i}}$ rise at 1 and $2 \mathrm{mmol} / \mathrm{l}$ $\mathrm{CaCl}_{2}$ stimulations, in the presence of R-568 in

Table 1 Calcimimetic R-568 effect on $\left[\mathrm{Ca}^{2+}\right]_{i}$ concentration in HEK-WT and HEK-990G cells

\begin{tabular}{|c|c|c|c|}
\hline & $\begin{array}{l}E_{50} \\
\text { HEK-WT }\end{array}$ & $\begin{array}{l}E_{50} \\
\text { HEK-990G }\end{array}$ & $\begin{array}{l}\boldsymbol{P} \text { value } \\
\text { (Student's } \\
t \text {-test) }\end{array}$ \\
\hline \multicolumn{4}{|c|}{ R-568 ( $\mu \mathrm{mol} / \mathrm{l})$} \\
\hline 0 & $4 \cdot 49 \pm 0 \cdot 15$ & $2 \cdot 69 \pm 0 \cdot 11$ & 0.0001 \\
\hline 0.01 & $4.31 \pm 0.09$ & $2 \cdot 72 \pm 0.20$ & 0.0001 \\
\hline 0.05 & $3 \cdot 38 \pm 0 \cdot 12$ & $2 \cdot 85 \pm 0 \cdot 14$ & 0.0087 \\
\hline $0 \cdot 1$ & $2 \cdot 40 \pm 0.13$ & $2 \cdot 10 \pm 0 \cdot 22$ & NS \\
\hline 0.5 & $1.77 \pm 0.23$ & $1 \cdot 48 \pm 0 \cdot 15$ & NS \\
\hline 1 & $1.38 \pm 0.07$ & $1.44 \pm 0.05$ & NS \\
\hline 2 & $1.41 \pm 0.06$ & $1 \cdot 24 \pm 0 \cdot 10$ & NS \\
\hline
\end{tabular}

NS, not statistically significant. 


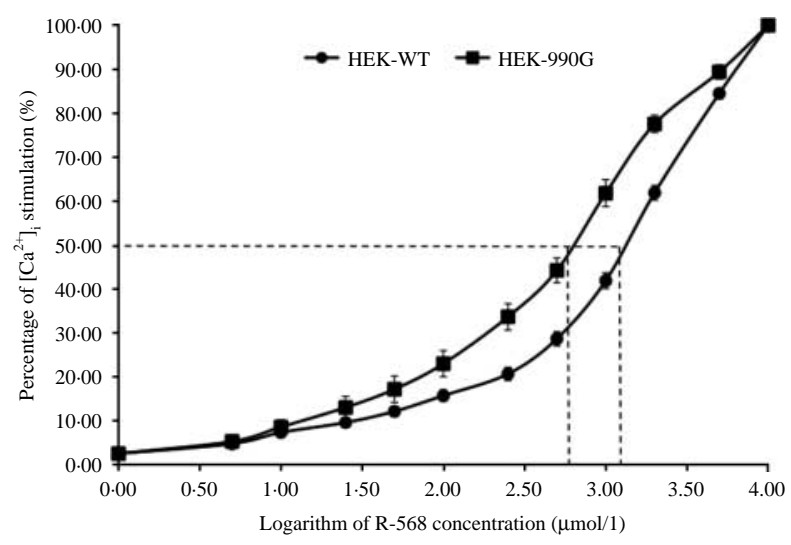

Figure 2 Response to calcimimetic R-568 in HEK-WT and HEK-990G cells. HEK-WT and HEK-990G cells were loaded with fura-2 and stimulated by increasing R-568 concentrations in the presence of $1 \mathrm{mmol} / / \mathrm{CaCl}_{2}$. The response was normalized and the percentage of $\left[\mathrm{Ca}^{2+}\right]_{i}$ stimulation was plotted against the logarithm of R-568 concentrations. The dotted lines indicate the logarithmic values of $\mathrm{R}-568 \mathrm{EC}_{50}$. Values shown are means \pm S.E.M. of three replicates.

HEK-990G compared to HEK-WT cells (Fig. 4); and 3 ) the appearance of the oscillations already at $2 \mathrm{mmol} / \mathrm{l} \mathrm{CaCl}_{2}$ in the presence of 0.05 and $0 \cdot 1 \mu \mathrm{mol} / 1 \mathrm{R}-568$ (Table 2).

The exposure to R-568 at different concentrations determined changes in the oscillation pattern in HEK-WT and particularly in HEK-990G cells. The proportion of oscillating HEK-990G cells at $0.01 \mu \mathrm{mol} / 1 \mathrm{R}-568$ was higher than that of HEK-WT, while the difference disappeared with increasing calcimimetic concentration (Table 2). Analyzing the oscillation pattern, although the proportion of transient oscillations was similar in both cell lines at all R-568 concentrations, the proportion of sinusoidal oscillations was higher in HEK-990G at $0.01 \mu \mathrm{mol} / \mathrm{l}$ R-568, accounting for the observed difference in the overall proportion of oscillating cells. The difference disappeared with increasing R-568 concentrations (Table 2). ANOVA analysis showed that increasing R-568 concentration in both cell lines reduced transient oscillations, while sinusoidal oscillations gradually increased in HEK-WT cells only (Table 2). Therefore, the oscillation pattern shifted in a large percentage of cells from a transient to a sinusoidal one at $4 \mathrm{mmol} / 1 \mathrm{CaCl}_{2}$ with higher R-568 concentrations (Table 2). Finally, the oscillation frequency was similar in the two cell lines in all the experimental conditions $(3 \cdot 46 \pm 0 \cdot 17$ and $3 \cdot 03$ \pm 0.09 oscillation/min, for HEK-WT and HEK-990G cells respectively). Hence, all these data indicate that HEK-990G cells were more responsive to the R-568 than HEK-WT cells.

\section{Effect of inhibitors and activators of CASR signaling pathways}

The effects of inhibitors and activators of some components of the CASR signaling pathways were analyzed by single-cell experiments. The pretreatment with $1 \mu \mathrm{mol} / 1$ SERCA inhibitor thapsigargin, which rapidly depletes intracellular $\mathrm{Ca}^{2+}$ stores, completely blocked oscillations in both cell lines (Fig. 5A and B). The same effect was obtained with the PLC inhibitor U73122 $(10 \mu \mathrm{mol} / \mathrm{l}$; Fig. 5C and D). These results indicate that $\left[\mathrm{Ca}^{2+}\right]_{\mathrm{i}}$ oscillations depend on the intracellular calcium pools and $\mathrm{IP}_{3}$ pathway.

The pretreatment with the PKC inhibitor Ro 31-8220 at $1.25 \mu \mathrm{mol} / 1$ concentration differentially affected
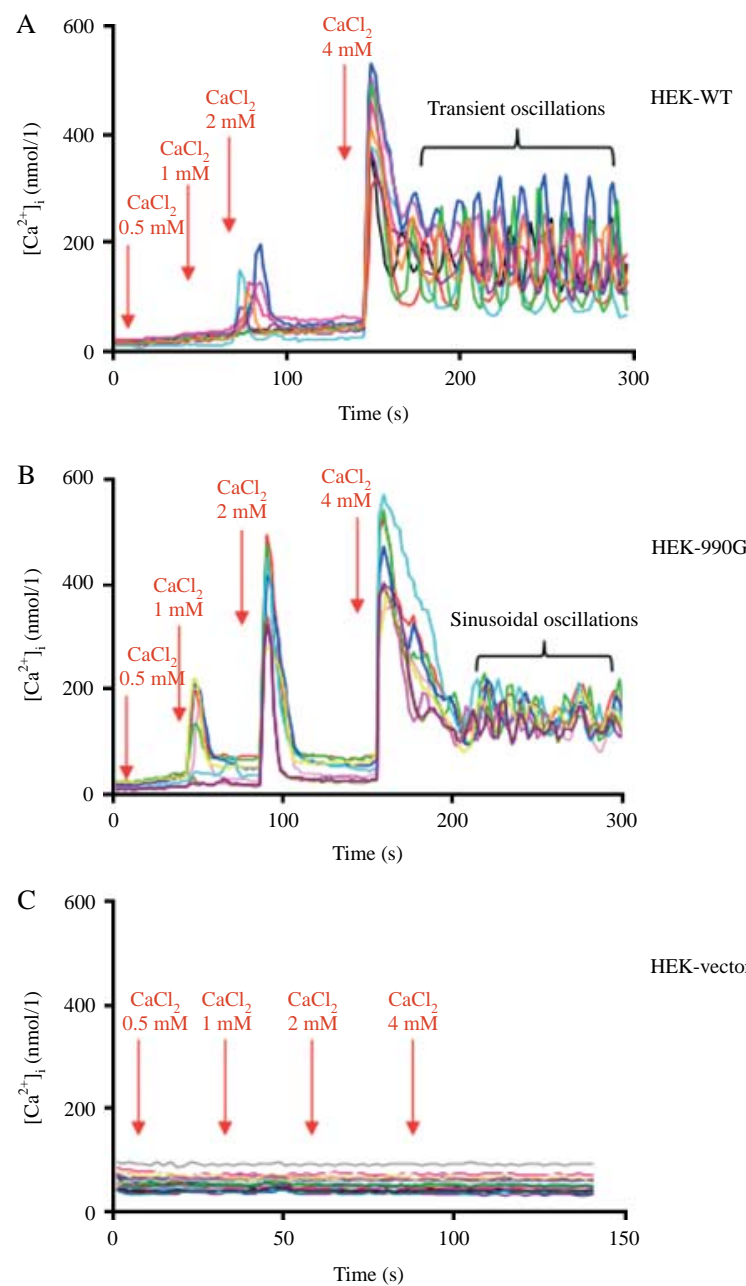

Figure 3 Effect of increasing $\left[\mathrm{Ca}^{2+}\right]_{\mathrm{o}}$ on $\left[\mathrm{Ca}^{2+}\right]_{\mathrm{i}}$ peaks and oscillations. Time course of $\left[\mathrm{Ca}^{2+}\right]_{i}$ in the different cell lines was analyzed after stimulations with increasing extracellular calcium $\left(0.5,1,2\right.$, and $\left.4 \mathrm{mmol} / \mathrm{I} \mathrm{CaCl}_{2}\right)$. Arrows indicate $\mathrm{CaCl}_{2}$ additions. Curly brackets indicate oscillation events. Traces are representative of three to six similar experiments in HEK-WT (A), HEK-990G (B), and HEK-vector (C). Each line represents behavior of a single cell, randomly chosen. 

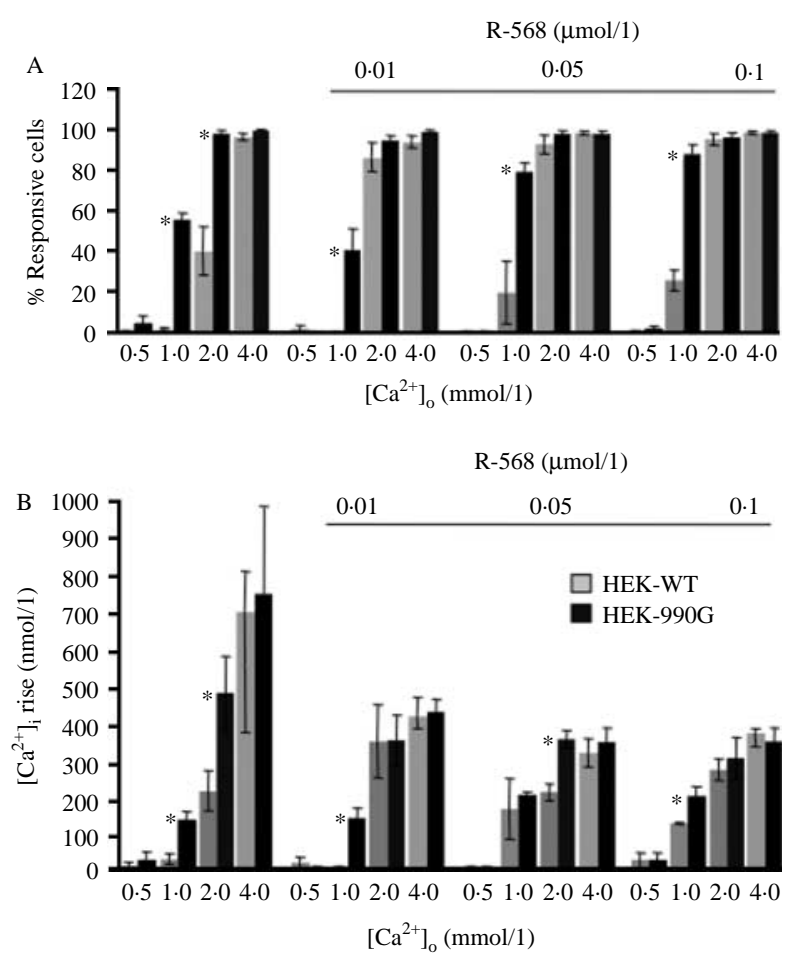

Figure 4 Percentage of responsive cells and $\left[\mathrm{Ca}^{2+}\right]_{\mathrm{i}}$ rise $(\mathrm{nmol} / \mathrm{l})$ in the presence of different concentrations of R-568. HEK-WT and HEK-990G cells, loaded with fura-2, were stimulated by $\left[\mathrm{Ca}^{2+}\right]_{0}$ in the presence or absence of calcimimetic R-568 in single-cell experiments. Mean values of $\left[\mathrm{Ca}^{2+}\right]_{i}$ rise $(A)$ and percentage of responsive cells $(B)$ were calculated as described in the 'Materials and methods' section. ${ }^{\star} P<0.05$ between HEK-WT and HEK-990G cells.

$\left[\mathrm{Ca}^{2+}\right]_{\mathrm{i}}$ oscillations in HEK-WT and HEK-990G cells. In fact, $\left[\mathrm{Ca}^{2+}\right]_{\mathrm{i}}$ oscillations generated by $4 \mathrm{mmol} / \mathrm{l} \mathrm{CaCl}_{2}$ were markedly reduced in pretreated HEK-WT cells, while preincubation with this inhibitor did not affect oscillation pattern and frequency in HEK-990G (Fig. 6A and B). A tested lower dose of Ro 31-8220 $(0 \cdot 625 \mu \mathrm{mol} / \mathrm{l})$ was ineffective in both kinds of cells, while a higher dose of Ro 31-8220 (2.5 $\mu \mathrm{mol} / \mathrm{l})$ was toxic. The PKC activator PDBu $(0 \cdot 01,0 \cdot 5$, and $0 \cdot 1 \mu \mathrm{mol} / \mathrm{l})$ drastically reduced $\left[\mathrm{Ca}^{2+}\right]_{\mathrm{i}}$ oscillations in presence of $4 \mathrm{mmol} / \mathrm{l}$ $\mathrm{CaCl}_{2}$, with no differences between the two cell lines (Fig. 6C and D).

Control experiments were also performed on HEKWT and HEK-990G cells with DMSO, used as vehicle of the inhibitors and activators, and no cell responses were monitored (data not shown).

\section{Effect of CASR activation by $\left[\mathrm{Ca}^{2+}\right]_{\mathrm{o}}$ and calcimimetic R-568 on p44/42 ERK phosphorylation}

Exposure to $\mathrm{CaCl}_{2}$ (from 0.5 to $1.0 \mathrm{mmol} / \mathrm{l}$ ) caused no effect on p44/42 ERK phosphorylation in HEK-WT cells, while it induced an 80\% increase in p44/42 ERK phosphorylation in HEK-990G cells. The maximal p44/42 ERK phosphorylation response was observed at $5.0 \mathrm{mmol} / 1 \mathrm{CaCl}_{2}$ in both cell lines, while no further increase was observed at $\mathrm{CaCl}_{2}$ up to $15 \mathrm{mmol} / \mathrm{l}$ (Fig. 7 and data not shown). The mean Ca-EC 50 value was lower in HEK-990G $(0.93 \pm 0.20 \mathrm{mmol} / \mathrm{l})$ than in HEK-WT cells $(2 \cdot 46 \pm 0 \cdot 83 \mathrm{mmol} / 1, P=0 \cdot 046$; Fig. 7B). HEK-293 cells or cells transfected with empty plasmid showed no change in p44/42 ERK phosphorylation at any $\left[\mathrm{Ca}^{2+}\right]_{\mathrm{o}}$ tested (data not shown).

The effect of R-568 on CASR-induced increase in p44/42 ERK phosphorylation was tested. In HEK-990G cells, the lowest R-568 concentration $(0 \cdot 01 \mu \mathrm{mol} / \mathrm{l})$ was able to induce the maximal p44/42 ERK phosphorylation at $3 \mathrm{mmol} / 1 \mathrm{CaCl}_{2}$ (Fig. $8 \mathrm{~A}$ and $\mathrm{B}$ ), while in HEKWT cells a leftward shift of the dose-response curve was observed by increasing R-568 concentrations to $0 \cdot 05$ and $0 \cdot 1 \mu \mathrm{mol} / 1$ (Fig. 8B). The mean Ca-EC 50 values in presence of $0 \cdot 01 \mu \mathrm{mol} / 1 \mathrm{R}-568$ were significantly lower in HEK-990G than in HEK-WT $(3 \cdot 18 \pm 0 \cdot 06$ vs $1.79 \pm 0.01 \mathrm{mmol} / 1$ respectively, $P=0.002$; Table 3 ). In HEK-990G cells, the Ca-EC 50 values were not further reduced by increasing R-568 concentrations to 0.05 and $0.1 \mu \mathrm{mol} / 1$, while in HEK-WT, Ca-EC ${ }_{50}$ values showed a trend to reduce by increasing drug concentration from 0.01 to $0.05 \mu \mathrm{mol} / \mathrm{l}$ R-568 that became significant at $0 \cdot 1 \mu \mathrm{mol} / 1 \mathrm{R}-568$ (Fig. 8 and Table 3).

Table 2 Percentage of oscillating cells in the presence of different R-568 concentrations

\begin{tabular}{|c|c|c|c|c|c|c|c|c|}
\hline R-568 $(\mu \mathrm{mol} / \mathrm{l})$ & \multicolumn{2}{|l|}{0} & \multicolumn{2}{|l|}{0.01} & \multicolumn{2}{|l|}{0.05} & \multicolumn{2}{|l|}{0.1} \\
\hline $\begin{array}{l}\text { Percentage of oscillating } \\
\text { cells }\end{array}$ & $59 \cdot 52 \pm 5 \cdot 53$ & $79 \cdot 85 \pm 5 \cdot 42^{\mathrm{a}}$ & $35 \cdot 85 \pm 8 \cdot 04$ & $78 \cdot 74 \pm 4 \cdot 66^{b}$ & $45 \cdot 88 \pm 11 \cdot 13$ & $54 \cdot 23 \pm 5 \cdot 23$ & $52 \cdot 40 \pm 6 \cdot 44$ & $44 \cdot 01 \pm 7 \cdot 88$ \\
\hline $\begin{array}{l}\text { Percentage of transient } \\
\text { oscillating cells }\end{array}$ & $51 \cdot 45 \pm 5 \cdot 98$ & $55 \cdot 46 \pm 5 \cdot 72$ & $24 \cdot 71 \pm 5 \cdot 01$ & $39 \cdot 91 \pm 10 \cdot 79$ & $26 \cdot 82 \pm 7 \cdot 08$ & $18 \cdot 98 \pm 5 \cdot 58$ & $11 \cdot 34 \pm 4 \cdot 04^{e}$ & $14 \cdot 03 \pm 7 \cdot 61^{g}$ \\
\hline $\begin{array}{l}\text { Percentage of sinusoidal } \\
\text { oscillating cells }\end{array}$ & $8 \cdot 07 \pm 2 \cdot 67$ & $24 \cdot 39 \pm 4 \cdot 89^{b}$ & $11 \cdot 14 \pm 4 \cdot 11$ & $38 \cdot 83 \pm 6 \cdot 30^{d}$ & $19 \cdot 06 \pm 6 \cdot 17$ & $35 \cdot 15 \pm 4 \cdot 21$ & $41 \cdot 06 \pm 6 \cdot 49^{f}$ & $29 \cdot 98 \pm 3 \cdot 63$ \\
\hline
\end{tabular}

Student's $t$-test for HEK-990G vs HEK-WT, $P$ values: ${ }^{\mathrm{a}} 0 \cdot 0216,{ }^{\mathrm{b}} 0 \cdot 0036,{ }^{\mathrm{c}} 0 \cdot 0095,{ }^{\mathrm{d}} 0 \cdot 0065$. One-way ANOVA for HEK-WT, $P$ values: ${ }^{\mathrm{e}} 0 \cdot 0003,{ }^{\mathrm{f}} 0 \cdot 0002$. One-way ANOVA for HEK-990G, $P$ values: ${ }^{9} 0.0027$. 

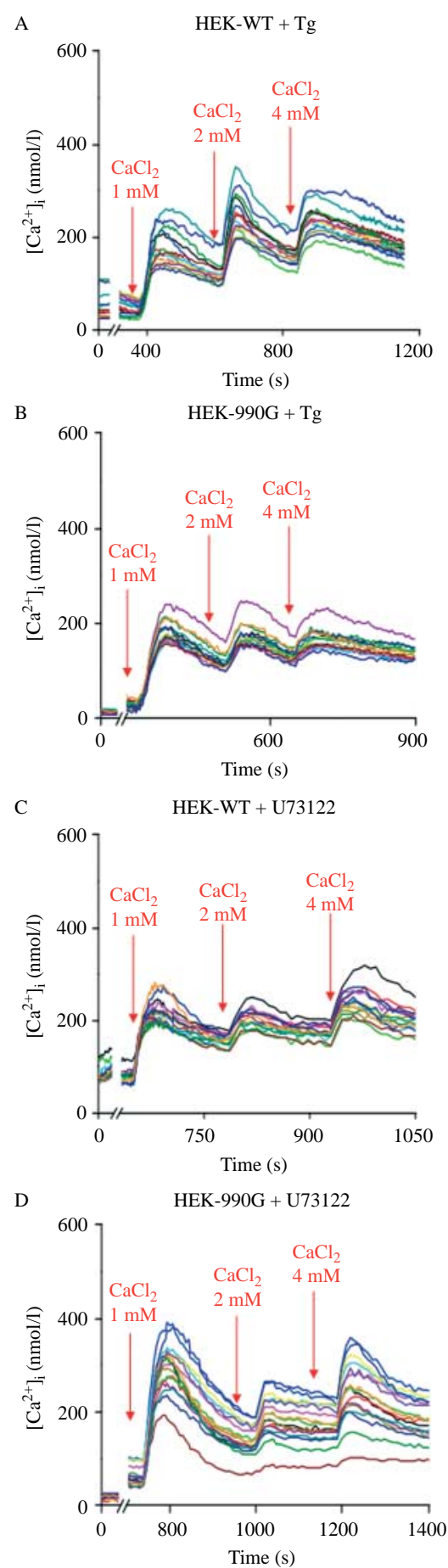

Figure 5 Effect of sarco/endoplasmic reticulum $\mathrm{Ca}^{2+}$-ATPase (SERCA) inhibitor and phospholipase C (PLC) inhibitor on $\left[\mathrm{Ca}^{2+}\right]_{\mathrm{i}}$ oscillation. Oscillations and time course variations of $\left[\mathrm{Ca}^{2+}\right]_{i}$ measured after pretreatment with SERCA inhibitor thapsigargin $(1 \mu \mathrm{mol} / \mathrm{l}, \mathrm{A}$ and $\mathrm{B})$ and PLC inhibitor U73122 (10 $\mu \mathrm{mol} / \mathrm{l}, \mathrm{C}$ and $\mathrm{D})$, at each $\mathrm{CaCl}_{2}$ concentrations tested in HEK-WT cells $(A$ and $C)$ and in HEK-990G cells (B and D). Arrows indicate $\mathrm{CaCl}_{2}$ additions. Traces are representative of three to six similar experiments. Each line represents behavior of a single cell, randomly chosen.

\section{Discussion}

Our study confirms that the R990G polymorphic CASR is more sensitive than the WT receptor to extracellular calcium and provides new evidence for an increased sensitivity of this receptor to the calcimimetic R-568. This study investigated in detail several intracellular events generated by CASR activation. First, as calcium oscillations have been postulated to dynamically increase the cross talk between multiple signaling pathways to generate complex responses, the oscillatory patterns of $\left[\mathrm{Ca}^{2+}\right]_{\mathrm{i}}$ elicited by $\mathrm{CaCl}_{2}$ and the calcimimetic were extensively studied in single-cell experiments. Two different oscillatory patterns were described: 1) transient oscillations, with a baseline spiking behavior and 2) sinusoidal oscillations, with an elevated-line spiking. Both patterns, which may occur in the same cell in response to different stimuli or to changes in agonist concentration, have been hypothesized to generate different signaling pathways (Rey et al. 2005). In agreement with previous studies (Breitwieser \& Gama 2001, Young \& Rozengurt 2002, Rey et al. 2005), HEK-293 cells transfected with the human WT CASR responded to increases in $\left[\mathrm{Ca}^{2+}\right]_{\mathrm{o}}$ to physiological level $(2 \mathrm{mmol} / \mathrm{l})$ with a single transient $\mathrm{Ca}^{2+}$ spike and to higher $\left[\mathrm{Ca}^{2+}\right]_{\mathrm{o}}$ concentration with $\left[\mathrm{Ca}^{2+}\right]_{\mathrm{i}}$ oscillations. In agreement with our previous results obtained in whole cell population (Vezzoli et al. 2007), the single cells transfected with the CASR variant 990G allele were more sensitive to extracellular calcium. The calcimimetic R-568 had a profound effect on the oscillatory pattern. In fact, increasing R-568 concentrations reduced transient oscillations in both cell lines, while sinusoidal oscillations gradually increased in HEK-WT cells. This shift of the oscillation pattern from transient to sinusoidal is usually observed when the $\left[\mathrm{Ca}^{2+}\right]_{\mathrm{o}}$ is persistently elevated. At variance, HEK-990G cells display a significant percentage of sinusoidal oscillations also in the absence of R-568, a percentage not statistically modified by the increasing concentration of R-568. It is worth noting that the two oscillatory patterns are related to different mechanisms of activation. Transient oscillations seem to be controlled by activation of phosphoinositide pathway and are influenced by agonist concentrations and phorbol esters (PKC activators; Berridge \& Potter 1990), while sinusoidal oscillations seem to result from a negative feedback loop involving inhibition of $\mathrm{IP}_{3}$ production by PKC (Bird et al. 1993). Moreover, Bird et al. stated that full activation or inhibition of $\mathrm{PKC}$ is incompatible with sinusoidal oscillations.

Therefore, it can be speculated a difference in the level of PKC activity between HEK-WT and HEK-990G cells, a difference that becomes important when the calcimimetic R-568 is administered to cells. The increase in the percentage of sinusoidal oscillations in 

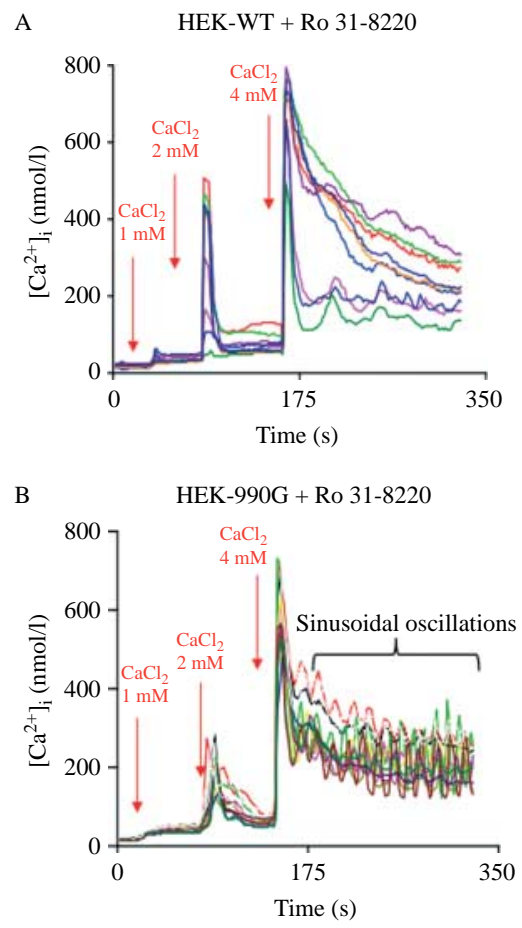

C
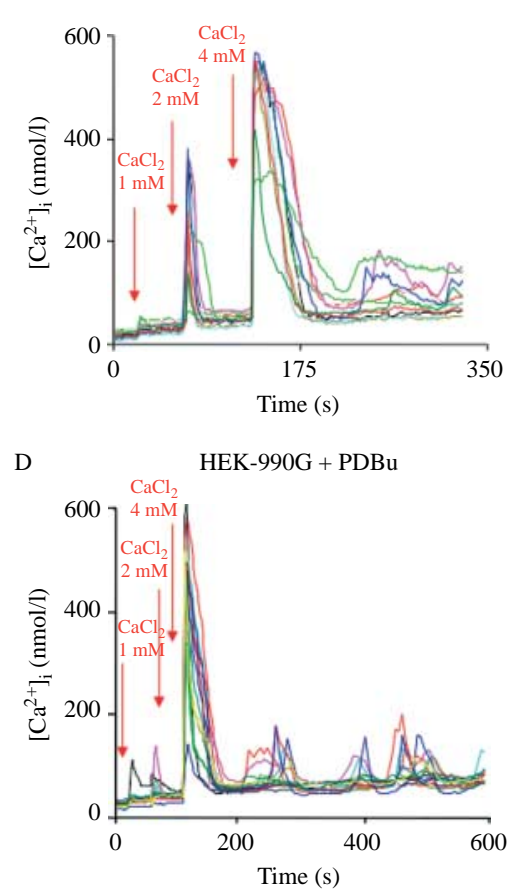

Figure 6 Effects of PKC inhibitor or activator. Time course of $\left[\mathrm{Ca}^{2+}\right]_{i}$ after cell pretreatment with the PKC inhibitor Ro 31-8220 $1.25 \mu \mathrm{mol} / \mathrm{I}(\mathrm{A}$ and $\mathrm{B}$ ) and the PKC activator PDBu $0.1 \mu \mathrm{mol} / \mathrm{I}$ ( $C$ and $D$ ) in HEK-WT cells ( $A$ and $C$ ) and in HEK-990G cells (B and D). Arrows indicate $\mathrm{CaCl}_{2}$ additions. Curly brackets indicate oscillation events. Traces are representative of three to six similar experiments. Each line represents behavior of a single cell, randomly chosen.
HEK-WT cells due to the calcimimetic R-568 could be ascribed to a pharmacological modification of PKC activity, resulting in the modulation of this activity toward a fluctuating level able to affect $\mathrm{IP}_{3}$ production and $\left[\mathrm{Ca}^{2+}\right]_{\mathrm{i}}$. This hypothesis, as well as its pharmacological significance, deserves further investigation.

As far as the oscillation frequency was concerned, this was similar in HEK-WT and HEK-990G cells and consistent with the reported values (Young et al. 2002, Szekely et al. 2009). The dose-dependent increase in oscillation frequencies reported previously was obtained at high calcimimetic concentrations (1-10 $\mu \mathrm{M}$; Miedlich et al. 2002).

Second, we investigated some components of the pathways involved in $\left[\mathrm{Ca}^{2+}\right]_{\mathrm{i}}$ oscillations. Indeed, the exact mechanisms responsible for inducing, maintaining, and ending of $\left[\mathrm{Ca}^{2+}\right]_{\mathrm{i}}$ oscillations are still largely unknown. The major pathway seems to involve calcium influx and efflux mediated by PLC and $\mathrm{IP}_{3}$, implicating intracellular stores. In this study, both SERCA and PLC inhibitors, which act at two different levels of the $\mathrm{IP}_{3}$ pathway, were effective in preventing the oscillatory

A
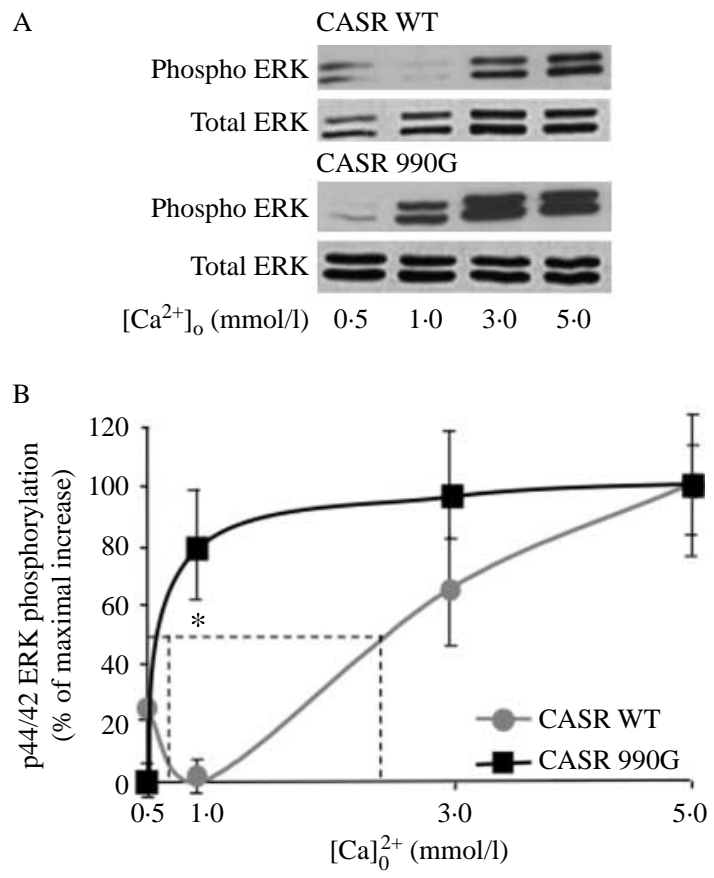

Figure 7 Effect of increasing $\left[\mathrm{Ca}^{2+}\right]_{\mathrm{o}}$ on p44/42 ERK phosphorylation. (A) Representative immunoblots of phosphorylated and total p44/42 extracellular signaling-regulated kinase (ERK) in HEK-WT (upper set) and HEK-990G (lower set) stimulated by increasing $\mathrm{CaCl}_{2}$ concentrations. (B) Dose-response curve of p44/42 ERK phosphorylation. The response was normalized to the maximal effect obtained by $\mathrm{CaCl}_{2}$ and the percentage of phosphorylation was subtracted to the basal level at $0.5 \mathrm{mmol} / \mathrm{l}$ $\mathrm{CaCl}_{2}$. Values shown are means \pm s.E.M. of three replicates. The dotted lines indicate the mean values of $\mathrm{Ca}-\mathrm{EC}_{50}$. ${ }^{*} P=0.01$ between HEK-WT and HEK-990G cells. 

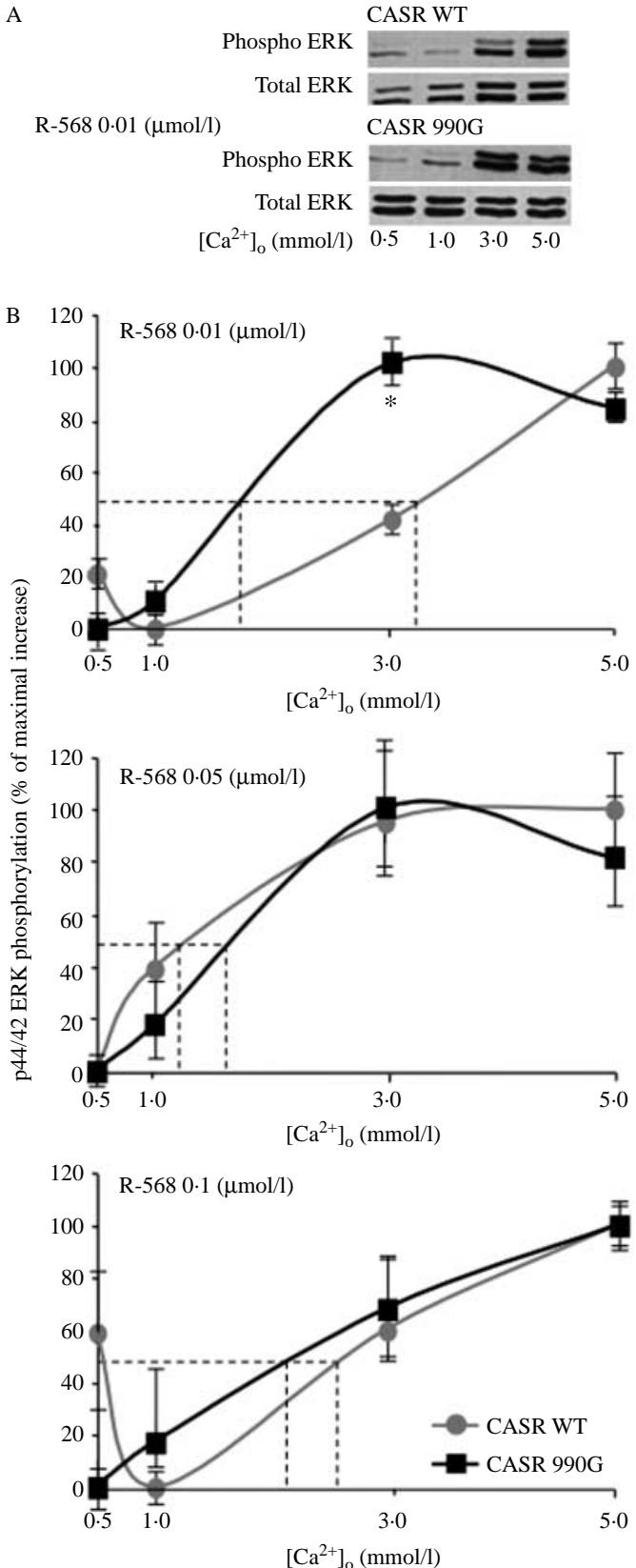

Figure 8 Effect of increasing concentrations of R-568 on $\mathrm{Ca}^{2+}$-evoked $\mathrm{p} 44 / 42$ extracellular signaling-regulated kinase (ERK) phosphorylation in HEK-WT and HEK-990G cells. (A) Representative immunoblots of phosphorylated and total p44/42 ERK in HEK-WT (upper set) and HEK-990G (lower set) stimulated by increasing $\mathrm{CaCl}_{2}$ concentrations in presence of $0.01 \mu \mathrm{mol} / \mathrm{l} \mathrm{R}-568$. (B) Dose-response curve of p44/42 ERK phosphorylation was calculated in presence of R-568 (0.01, 0.05 , and $0.1 \mu \mathrm{mol} / \mathrm{l}$, from the top to the bottom). The response was normalized to the maximal effect obtained by $\left[\mathrm{Ca}^{2+}\right]_{0}$. Values shown are means \pm S.E.M. of three replicates. The dotted lines indicate the mean values of $\mathrm{Ca}-\mathrm{EC}_{50} .{ }^{*} P<0.05$ between HEK-WT and HEK-990G cells. responses in both cell lines, indicating that this pathway is required for $\left[\mathrm{Ca}^{2+}\right]_{\mathrm{i}}$ oscillations.

However, other regulating mechanisms have been hypothesized to explain $\left[\mathrm{Ca}^{2+}\right]_{\mathrm{i}}$ oscillations, such as the negative feedback due to PKC-induced phosphorylation at $\mathrm{Thr}^{888}$ residue of CASR intracellular domain. Young \& Rozengurt (2002) and Young et al. (2002) found that PKC had a negative effect on $\left[\mathrm{Ca}^{2+}\right]_{i}$ oscillations mediated by the CASR, both with inactive and activated PKC. In fact, the T888A CASR mutant, which is not phosphorylated by PKC at this residue, reduced $\left[\mathrm{Ca}^{2+}\right]_{\mathrm{i}}$ oscillations. However, the PKC activator $\mathrm{PDBu}$ produced the same reduction on the WT CASR. In agreement with these data, our study suggests that PKC plays a critical role in $\left[\mathrm{Ca}^{2+}\right]_{\mathrm{i}}$ oscillations elicited by the increase of $\left[\mathrm{Ca}^{2+}\right]_{0}$ in HEK-WT. In fact, both the PKC inhibitor Ro 31-8220 and PKC activator PDBu significantly reduced oscillatory responses triggered by $\left[\mathrm{Ca}^{2+}\right]_{\mathrm{o}}$ increases, without affecting $\left[\mathrm{Ca}^{2+}\right]_{\mathrm{i}}$ peaks. Conversely, in HEK-990G cells, while the activator PDBu resulted in an almost complete inhibition of oscillations, the PKC inhibitor Ro 31-8220 seemed not to influence the presence of oscillations. These data suggest that a subsidiary mechanism, not operative for the WT receptor, might maintain the oscillatory response of CASR 990G in the absence of PKC. Moreover, we can speculate that calcium transients remained active in presence of $\mathrm{PKC}$ modulators because they are triggered by the PLC-IP 3 pathway, upstream PKC (Young \& Rozengurt 2002). Studies on CASR and PKC isoforms demonstrated that both conventional and novel PKC isoforms are activated by $\left[\mathrm{Ca}^{2+}\right]_{\mathrm{o}}$ increases (Remy et al. 2007) and PKC-specific inhibitors did not completely abolish ERK1/2 phosphorylation (Sakwe et al. 2004). Novel PKCs $(\delta, \varepsilon, \eta$, and $\theta)$ are activated by $\left[\mathrm{Ca}^{2+}\right]_{\mathrm{i}}$ and diacyl glycerol, whereas conventional PKCs $(\alpha, \beta$, and $\gamma)$ are activated only by $\left[\mathrm{Ca}^{2+}\right]_{i}$, so we can speculate that the oscillatory response of CASR 990G could require only one PKC group (Oancea \& Meyer 1998, Young et al. 2002). Our data do not answer this question but demonstrate the shift of PKC pathway in HEK-990G cells. Further experimental work will be necessary to

Table 3 Calcimimetic R-568 effect on p44/42 extracellular signaling-regulated kinase phosphorylation in HEK-WT and HEK-990G cells

\begin{tabular}{|c|c|c|c|}
\hline & $\begin{array}{l}\text { EC }_{50} \\
\text { HEK-WT }\end{array}$ & $\begin{array}{l}\text { EC }_{50} \\
\text { HEK-990G }\end{array}$ & $\begin{array}{l}\boldsymbol{P} \text { value } \\
\text { (Student's } \\
t \text {-test) }\end{array}$ \\
\hline \multicolumn{4}{|c|}{ R-568 $(\mu \mathrm{mol} / \mathrm{l})$} \\
\hline 0.01 & $3 \cdot 18 \pm 0.06$ & $1.79 \pm 0.01$ & 0.002 \\
\hline 0.05 & $2 \cdot 13 \pm 0.45$ & $1.48 \pm 0.50$ & NS \\
\hline 0.1 & $2.48 \pm 0.02$ & $2 \cdot 22 \pm 1 \cdot 23$ & NS \\
\hline
\end{tabular}

NS, not statistically significant. 
fully understand the interaction between PKC isoforms and CASR in $\left[\mathrm{Ca}^{2+}\right]_{\mathrm{o}}$-evoked $\left[\mathrm{Ca}^{2+}\right]_{\mathrm{i}}$ oscillations.

Finally, we investigated components of the pathways involved in long-term effects of CASR activation. It is well known that CASR contributes to regulation of cellular processes, including cell proliferation, differentiation, and apoptosis through activation of the ERK cascade (Hofer \& Brown 2003). It has been demonstrated that the ERK pathway is involved in the modulation of PTH secretion (Corbetta et al. 2002) and growth factor-induced cyclin D1 expression (Corbetta et al. 2007b) in human parathyroid cells. CASR-mediated activation of MAPK signaling requires direct interaction of the CASR carboxyl terminal with the cytoskeleton scaffolding protein filamin A (Awata et al. 2001, Hjalm et al. 2001). Analyses by yeast twohybrid have identified strong interactions between filamin A and the CASR carboxyl terminus from residues 907 to 997 (Awata et al. 2001) and 972 to 1031 (Hjalm et al. 2001), suggesting that the minimal interaction domain is likely to be between residues 972 and 997. Indeed, MAPK signaling is dependent on the presence of an $\alpha$-helix (residues 868-879) shown previously to be involved in G-protein-mediated signaling. Furthermore, the interaction with filamin A stabilizes CASR and attenuates its degradation rate, facilitating MAPK signaling (Zhang \& Breitwieser 2005). Intensive mutagenesis suggests that the domain proximal to transmembrane helix 7 within the carboxyl terminus is involved in CASR-mediated activation of $\mathrm{G}_{\mathrm{q}}$, PKC-mediated desensitization, signaling to phosphatidylinositol PLC, and induction and maintenance of the intracellular $\mathrm{Ca}^{2+}$ oscillations (Gama \& Brietwieser 1999, Miedlich et al. 2002). In this study, we first demonstrated that the $990 \mathrm{G}$ polymorphic variant of the CASR activated p44/42 ERK phosphorylation in the short term (10 min). Moreover, the 990G allele was associated with a higher sensitivity to extracellular $\mathrm{Ca}^{2+}$ for the short-term activation of the p44/42 ERK pathway in comparison with the WT receptor. The potent CASR agonist R-568 efficiently increased the sensitivity of the WT CASR in terms of p44/42 ERK phosphorylation. The efficient activation of the 990G CASR in terms of p44/42 ERK phosphorylation has been observed even at lower R-568 concentrations. The binding site for R-568 has been identified within the transmembrane domain of human CASR (Holstein et al. 2004). R-568 has been demonstrated to stabilize WT and mutant CASR favoring the active receptor conformations (Miedlich et al. 2004). Our data were in line with previous observation of Huang \& Breitwieser (2007) who demonstrated that gain-of-function mutations increased the stability and activity of the receptor and that R-568 failed to further stabilize those mutants. R990G polymorphism was demonstrated to result in a gain-of-function (Vezzoli et al. 2007), so the changes in $\left[\mathrm{Ca}^{2+}\right]_{\mathrm{i}}$ response, oscillation pattern, and p44/42 ERK phosphorylation level, showed in this study, can be involved in a conformational checkpoint. We are tempted to speculate that the $990 \mathrm{G}$ activates an alternative pathway not modified by the R-568 action or maximally activated in basal conditions. Indeed, $\left[\mathrm{Ca}^{2+}\right]_{\mathrm{o}}$ and calcimimetic activation of ERK via separate pathways in HEK-WT cells had been suggested previously and the authors speculated that it might represent a nexus to differentially regulate cell differentiation vs proliferation via CASR activation (Sakwe et al. 2004).

In conclusion, our study confirms that the R990G polymorphic CASR is more sensitive than the WT receptor to extracellular calcium and provides new evidence for an increased sensitivity of this receptor to the calcimimetic R-568. Moreover, we found some different behaviors in cells expressing the WT or the mutant receptor, such as the insensitivity of HEK-990G cells to the PKC inhibitor, which could be a critical point in the CASR signaling. Admittedly, these data have been obtained in HEK-293 cells, a cell model extensively used for investigating CASR activity, due to the significant number of similarities with parathyroid cells. Therefore, the present data should be confirmed in a more physiological system, i.e. primary cell lines expressing CASR variants. If confirmed, these data might be relevant for future pharmacogenomic studies aimed to predict different responses to treatment in individuals with or without R990G allele, as reported in small series (Rothe et al. 2005). In this respect, our findings may be the rationale behind a clinical study assessing the therapeutical response to calcimimetic, such as cinacalcet, in patients carrying the R990G polymorphic CASR.

\section{Declaration of interest}

The authors declare that there is no conflict of interest that could be perceived as prejudicing the impartiality of the research reported.

\section{Funding}

This research was supported by the human therapeutics company AMGEN-Italia S.p.A, by Istituto Superiore di Sanità 'ITALIA-USA Program 2007 - Malattie Rare' grant no. 8900000 and by Ministero della Salute of Italy 'Progetto Oncologico 2006' (RF06ED01) and COFIN prot.2007EBR28J_003.

\section{Acknowledgements}

We thank Dr E A Caumo for mathematical support, as well as Drs J Hu and M Spiegel for providing the original human CASR plasmid. 


\section{References}

Awata H, Huang C, Handlogten ME \& Miller RT 2001 Interaction of the calcium-sensing receptor and filamin, a potential scaffolding protein. Journal of Biological Chemistry 276 34871-34879. (doi:10. 1074/jbc.M100775200)

Bai M, Quinn S, Trivedi S, Kifor O, Pearce SHS, Pollak MR, Krapcho K, Herbert SC \& Brown EM 1996 Expression and characterization of inactivating and activating mutation in the human $\mathrm{Ca}^{2+}{ }_{0}$-sensing receptor. Journal of Biological Chemistry 271 19537-19545. (doi:10. 1074/jbc.271.32.19537)

Bartlett PJ, Young KW, Nahorsky SR \& Challiss RA 2005 Single cell analysis and temporal profiling of agonist-mediated inositol 1,4,5,trisphosphate, $\mathrm{Ca}^{2+}$, diacylglycerol, and protein kinase $\mathrm{C}$ signaling using fluorescent biosensors. Journal of Biological Chemistry 280 21837-21846. (doi:10.1074/jbc.M411843200)

Berridge MJ \& Potter BV 1990 Inositol trisphosphate analogues induce different oscillatory patterns in Xenopus oocytes. Journal of Biological Chemistry 265 9583-9586.

Bird GS, Rossier MF, Obie JF \& Putney JW Jr 1993 Sinusoidal oscillations in intracellular calcium requiring negative feedback by protein kinase C. Journal of Biological Chemistry 268 8425-8428.

Block GA, Martin KJ, de Francisco ALM, Turner SA, Avram MM, Suranyi MG, Hercz G, Cunningham J, Abu-alfa AK, Messa P et al. 2004 Cinacalcet for secondary hyperparathyroidism in patients receiving hemodialysis. New England Journal of Medicine $\mathbf{3 5 0}$ 1516-1525. (doi:10.1056/NEJMoa031633)

Breitwieser GE \& Gama L 2001 Calcium-sensing receptor activation induces intracellular calcium oscillations. American Journal of Physiology. Cell Physiology 280 C1412-C1421.

Corbetta S, Lania A, Filopanti M, Vicentini L, Ballarè E \& Spada A 2002 Mitogen-activated protein kinase cascade in human normal and tumoral parathyroid cells. Journal of Clinical Endocrinology and Metabolism 87 2201-2205. (doi:10.1210/jc.87.5.2201)

Corbetta S, Eller-Vainicher C, Filopanti M, Saeli P, Vezzoli G, Arcidiacono T, Loli P, Syren ML, Soldati L, Beck-Pecoz P et al. 2007 a R990G polymorphism of the calcium-sensing receptor and renal calcium excretion in patients with primary hyperparathyroidism. European Journal of Endocrinology 155 687-692. (doi:10.1530/eje.1. 02286)

Corbetta S, Eller-Vainicher C, Vicentini L, Lania A, Mantovani G, Beck-Peccoz P \& Spada A 2007b Modulation of cyclin D1 expression in human tumoral parathyroid cells: effects of growth factors and calcium sensing receptor activation. Cancer Letters $\mathbf{2 5 5}$ 34-41. (doi:10.1016/j.canlet.2007.03.014)

Egbuna OI \& Brown EM 2008 Hypercalcaemic and hypocalcaemic conditions due to calcium-sensing receptor mutations. Best Practice and Research. Clinical Rheumatology 22 129-148. (doi:10.1016/j.berh. 2007.11.006)

Gama L \& Breitwieser GE 1999 Generation of epitope-tagged proteins by inverse PCR mutagenesis. Biotechniques 26 814-815.

Gama L, Baxendale-Cox LM \& Breitwieser GE $1997 \mathrm{Ca}^{2+}$-sensing receptors in intestinal epithelium. American Journal of Physiology 273 C1168-C1175.

Grynkiewicz G, Poenie GM \& Tsien RY 1985 A new generation of $\mathrm{Ca}^{2+}$ indicators with greatly improved fluorescence properties. Journal of Biological Chemistry 260 3440-3450.

Harding B, Curley AJ, Hannan FM, Christie PT, Bowl MR, Turner JJO, Barber M, Gillman-Nasenya I, Hampson G, Spector TD et al. 2006 Functional characterization of calcium sensing receptor polymorphisms and absence of association with indices of calcium homeostasis and bone mineral density. Clinical Endocrinology 65 598-605. (doi:10.1111/j.1365-2265.2006.02634.x)

Hjalm G, MacLeod RJ, Kifor O, Chattopadhyay N \& Brown EM 2001 Filamin-A binds to the carboxyl-terminal tail of the calcium-sensing receptor, an interaction that participates in CaR-mediated activation of mitogen-activated protein kinase. Journal of Biological Chemistry 276 34880-34887. (doi:10.1074/jbc.M100784200)
Hofer AM \& Brown EM 2003 Extracellular calcium sensing and signalling. Nature Reviews. Molecular Cell Biology 4 530-538. (doi:10. 1038/nrm1154)

Holstein DM, Berg KA, Leeb-Lundberg LM, Olson MS \& Saunders C 2004 Calcium-sensing receptor-mediated ERK1/2 activation requires Galphai2 coupling and dynamin-independent receptor internalization. Journal of Biological Chemistry 279 10060-10069. (doi:10.1074/jbc.M312039200)

Huang Y \& Breitwieser GE 2007 Rescue of calcium-sensing receptor mutants by allosteric modulators reveals a conformational checkpoint in receptor biogenesis. Journal of Biological Chemistry 282 9517-9525. (doi:10.1074/jbc.M609045200)

Huang C \& Miller RT 2007 The calcium-sensing receptor and its interacting proteins. Journal of Cellular and Molecular Medicine 11 923-934. (doi:10.1111/j.1582-4934.2007.00114.x)

Kelly C, Gunn IR, Gaffney D \& Devgun MS 2006 Serum calcium, urine calcium and polymorphisms of the calcium sensing receptor gene. Annals of Clinical Biochemistry 43 503-506. (doi:10.1258/ 000456306778904632)

Kupzig S, Walker SA \& Cullen PJ 2005 The frequencies of calcium oscillations are optimized for efficient calcium-mediated activation of Ras and ERK/MAPK cascade. PNAS 102 7577-7582. (doi:10. 1073/pnas.0409611102)

Lorenz S, Frenzel R, Paschke R, Breitwieser GE \& Miedlich SU 2007 Functional desensitization of the extracellular calciumsensing receptor is regulated via distinct mechanisms: role of $\mathrm{G}$ protein-coupled receptor kinases, protein kinase $\mathrm{C}$ and $\beta$-arrestins. Endocrinology 148 2398-2404. (doi:10.1210/ en.2006-1035)

Miedlich S, Gama L \& Breitwieser GE 2002 Calcium sensing receptor activation by a calcimimetic suggests a link between cooperativity and intracellular calcium oscillations. Journal of Biological Chemistry 277 49691-49699. (doi:10.1074/jbc.M205578200)

Miedlich SU, Gama L, Seuwen K, Wolf RM \& Breitwieser GE 2004 Homology modeling of the transmembrane domain of the human calcium sensing receptor and localization of an allosteric binding site. Journal of Biological Chemistry 279 7254-7263. (doi:10.1074/jbc. M307191200)

Mogami H, Zhang H, Suzuki Y, Urano T, Saito N, Kojima I \& Petersen OH 2003 Decoding of short-lived $\mathrm{Ca}^{2+}$ influx signals into log-term substrate phosphorylation through activation of two distinct classes of protein kinase C. Journal of Biological Chemistry 278 9896-9904. (doi:10.1074/jbc.M210653200)

Nemeth EF 2004 Calcimimetic and calcilytic drugs: just for parathyroid cells? Cell Calcium 35 283-289. (doi:10.1016/j.ceca.2003.10.020)

Nemeth EF, Steffey ME, Hammerland LG, Van Wagenen BC, DelMar EG \& Balandrin MF 1998 Calcimimetics with potent and selective activity on the parathyroid calcium receptor. PNAS 97 4040-4045. (doi:10.1073/pnas.95.7.4040)

Oancea E \& Meyer T 1998 Protein kinase C as a molecular machine for decoding calcium and diacylglycerol signals. Cell 95 307-318. (doi:10.1016/S0092-8674(00)81763-8)

Pearce SHS, Bai M, Quinn SJ, Kifor O, Brown EM \& Thakker RV 1996 Functional characterization of calcium-sensing receptor mutations expressed in human embryonic kidney cells. Journal of Clinical Investigation 98 1860-1866. (doi:10.1172/JCI118987)

Remy C, Kirchhoff P, Hafner P, Busque SM, Muller MK, Geibel JP \& Wagner CA 2007 Stimulation pathways of calcium-sensing receptor on acid secretion in freshly isolated human gastric glands. Cellular Physiology and Biochemistry 19 33-42. (doi:10.1159/ 000099190)

Rey O, Young SH, Yuan J, Slice L \& Rozengurt E 2005 Amino acidstimulated $\mathrm{Ca}^{2+}$ oscillations produced by the $\mathrm{Ca}^{2+}$-sensing receptor are mediated by a phospholipase $\mathrm{C} /$ inositol 1,4,5trisphosphate-independent pathway that requires G12, Rho, filamin-a, and the actin cytoskeleton. Journal of Biological Chemistry 280 22875-22882. (doi:10.1074/jbc.M503455200) 
Rothe HM, Shapiro WB, Sun WY \& Chou SY 2005 Calcium-sensing receptor gene polymorphism Arg990Gly and its possible effect on response to cinacalcet HCl. Pharmacogenetics and Genomics 15 29-34. (doi:10.1097/01213011-200501000-00005)

Sajid-Crockett S, Singer FR \& Hershman JM 2008 Cinacalcet for the treatment of primary hyperparathyroidism. Metabolism: Clinical and Experimental 57 517-521. (doi:10.1016/j.metabol.2007.11.014)

Sakwe AM, Larsson M \& Rask L 2004 Involvement of protein kinase $\mathrm{C}-\alpha$ and -epsilon in extracelllar $\mathrm{Ca}(2+)$ signalling mediated by the calcium sensing reporter. Experimental Cell Research 297 560-573. (doi:10.1016/j.yexcr.2004.03.039)

Scillitani A, Guarnieri V, De Geronimo S, Muscarella LA, Battista C, D'Agruma L, Bertoldo F, Florio C, Minisola S, Hendy GN et al. 2004 Blood ionized calcium is associated with clustered polymorphisms in the carboxyl-terminal tail of the calcium sensing receptor. Journal of Clinical Endocrinology and Metabolism 89 5634-5638. (doi:10.1210/jc.2004-0129)

Soderling TR, Chang B \& Brickey D 2001 Cellular signaling through multifunctional $\mathrm{Ca}^{2+} /$ calmodulin-dependent protein kinase II. Journal of Biological Chemistry 276 3719-3722. (doi:10.1074/jbc. R000013200)

Soldati L, Adamo D, Zerbi S, Caumo A, Spaventa R, Bianchi G \& Vezzoli G 1999 Erythrocyte voltage-dependent calcium influx is reduced in hemodialysis patients. Kidney International 56 190-197. (doi:10.1046/j.1523-1755.1999.00535.x)

Szekely D, Brennan SC, Mun HC, Conigrave AD \& Kuchel PW 2009 Effectors of the frequency of calcium oscillations in HEK-293 cells: wavelet analysis and a computer model. European Biophysics Journal 39 149-165. (doi:10.1007/s00249-009-0469-2)

Tfelt-Hansen J \& Brown EM 2005 The calcium-sensing receptor in normal physiology and pathophysiology: a review. Critical Reviews in Clinical Laboratory Sciences 42 35-70. (doi:10.1080/10408360590886606)

Trivedi R, Mithal A \& Chattopadhyay N 2008 Recent updates on the calcium-sensing receptor as a drug target. Current Medicinal Chemistry 15 178-186. (doi:10.2174/092986708783330601)

Vezzoli G, Tanini A, Ferrucci L, Soldati L, Bianchin C, Franceschelli F, Malentacchi C, Porfirio B, Adamo D, Terranegra A et al. 2002 Influence of calcium-sensing receptor gene on urinary calcium excretion in stone-forming patients. Journal of the American Society of Nephrology 13 2517-2523. (doi:10.1097/01.ASN.0000030077.72157.D2)

Vezzoli G, Terranegra A, Arcidiacono T, Biasion R, Coviello D, Syren ML, Paloschi V, Giannini S, Mignogna G, Rubinacci A et al. 2007
R990G polymorphism of calcium-sensing receptor does produce a gain-of-function and predispose to primary hypercalciuria. Kidney International 71 1155-1162. (doi:10.1038/sj.ki.5002156)

Wang O, Meng XW, Xing XP, Xia WB, Li M, Xu L, Zhou XY, Jiao J, Hu YY \& Liu H 2007 Association of calcium-sensing receptor gene polymorphism with serum calcium level in healthy young Han women in Beijing. Zhonghua Nei Ke Za Zhi 46 43-47.

Ward DT 2004 Calcium receptor-mediated intracellular signalling. Cell Calcium 35 217-228. (doi:10.1016/j.ceca.2003.10.017)

Yamauchi M, Sugimoto T, Yamaguchi T, Yano S, Kanzawa M, Kobayashi A \& Chihara K 2001 Association of polymorphic alleles of the calcium-sensing receptor gene with the clinical severity of primary hyperparathyroidism. Clinical Endocrinology 55 373-379. (doi:10. 1046/j.1365-2265.2001.01318.x)

Yano S, Sugimoto T, Kanzawa M, Tsukamoto T, Hattori T, Hattori S \& Chihara K 2000 Association of polymorphic alleles of the calciumsensing receptor gene with parathyroid hormone secretion in hemodialysis patients. Nephron 85 317-323. (doi:10.1159/ 000045681)

Yokoyama K, Shigematsu T, Tsukada T, Hara S, Yamada A, Kawaguchi Y \& Hosoya T 2002 Calcium-sensing receptor gene polymorphism affects the parathyroid response to moderate hypercalcemic suppression in patients with end-stage renal disease. Clinical Nephrology 57 131-135.

Young SH \& Rozengurt E 2002 Amino acids and $\mathrm{Ca}^{2+}$ stimulate different patterns of $\mathrm{Ca}^{2+}$ oscillations through the $\mathrm{Ca}^{2+}$-sensing receptor. American Journal of Physiology. Cell Physiology 282 C1414-C1422. (doi:10.1152/ajpcell.00432.2001)

Young SH, Wu SV \& Rozengurt E $2002 \mathrm{Ca}^{2+}$-stimulated $\mathrm{Ca}^{2+}$ oscillations produced by the $\mathrm{Ca}^{2+}$-sensing receptor require negative feedback by protein kinase C. Journal of Biological Chemistry 277 46871-46876. (doi:10.1074/jbc.M207083200)

Zhang M \& Breitwieser GE 2005 High affinity interaction with filamin A protects against calcium-sensing receptor degradation. Journal of Biological Chemistry 280 11140-11146. (doi:10.1074/jbc. M412242200)

Received in final form 27 July 2010 Accepted 3 August 2010 Made available online as an Accepted Preprint 3 August 2010 